\title{
Implementasi Metode Fuzzy TOPSIS untuk Seleksi Penerimaan Karyawan
}

\author{
S. Lestari dan W. Priyodiprodjo
}

\begin{abstract}
An emerging institution would continue to need qualified workers to produce good performances. Seeing the importance of high quality employees, the candidate selection process became an important part and should be performed promptly. It is also important to have candidates with desirable criteria fit to the institution. Many proposed methods can be adapted to help employee selection process based on criteria. This research propose an employee selection system based on Fuzzy Technique for Order Preference by Similarity to Ideal Solution (TOPSIS) method, because the proposed method capable to deal with multi dimensional problems in employees selection. The system will produce ranks that can be used to help the hiring decision. This research also compares the results from TOPSIS method and WPM method. The comparison result shows that both methods produce the same ranks for the chosen candidates.
\end{abstract}

Keywords- Fuzzy TOPSIS, WPM, Employee Selection.

\section{PENDAhUluan}

$I^{\prime}$ ndonesia merupakan negara yang memiliki jumlah penduduk yang demikian banyak, dan jumlah tenaga kerja terus mengalami peningkatan setiap tahunnya hal ini bermunculan dari berbagai jenis tingkat pendidikan. Pada saat suatu perusahaan membutuhkan karyawan, maka akan membuka lowongan pekerjaan, dan dalam waktu yang singkat biasanya akan dibanjiri oleh berkasberkas dari para pencari kerja. Permasalahan mulai terjadi, terkadang perusahaan mengalami kesulitan dalam menyaring pelamar pekerjaan, sehingga pelamar yang sebenarnya tidak memenuhi kriteria atau kebutuhan diikutkan dalam proses wawancara, atau bahkan diterima bekerja di perusahaan tersebut, sehingga perusahaan akan memiliki tenaga kerja yang sebenarnya tidak sesuai dengan kebutuhan perusahaan. Hal ini secara tidak langsung dapat menghambat produktivitas perusahaan itu sendiri.

Sri Lestari, staf pengajar Jurusan Sistem Informasi, IBI Darmajaya, Jl. ZA. Pagar Alam No. 93 Labuhan Ratu, Bandar Lampung 35142 (e-mail : t4ry09@yahoo.com)

Widodo Priyodiprodjo, staf pengajar Jurusan Ilmu Komputer dan Elektronika, FMIPA UGM, Gedung Student Internet Center (SIC) Lantai III, Skip Utara, Yogyakarta 55281(e-mail widodopri@gmail.com)
Salah satu cara mengatasi masalah tersebut adalah adanya suatu sistem yang dapat memberikan rekomendasi sebagai bahan pertimbangan untuk pengambilan keputusan secara tepat. Hal ini melatarbelakangi pengembangan sistem penyeleksian calon karyawan dengan mengimplementasikan metode Technique for Order Preference by Similarity to Ideal Solution (TOPSIS).

Terdapat beberapa artikel dan penelitian mengenai Fuzzy TOPSIS, seperti yang dilakukan oleh Salehi dan Moghaddam [1] mengusulkan teknik Fuzzy TOPSIS untuk masalah pemilihan proyek. Wang dan Kao [2] mengusulkan FMCDM dengan metode fuzzy TOPSIS untuk evaluasi performa operasi bandara. Hu et al. [3] mengajukan metode baru fuzzy TOPSIS untuk pemilihan lokasi pusat distribusi. Sukerti [4] mengusulkan metode TOPSIS untuk menentukan desa penerima bantuan program community based development (CBD) Bali Sejahtera. Penelitian yang pernah dilakukan untuk seleksi penerimaan calon karyawan diantaranya adalah Santoso [5] dan Rahino [6] menggunakan metode penilaian dan pembobotan secara matematis yang diproses secara otomatis oleh sistem. Santoso et al. [7] mengusulkan metode ANP (Analytic Network Process) digunakan untuk pemilihan calon pegawai. Akhiro [8] mengusulkan metode WPM (Weighted Product Model) untuk sistem rekomendasi pada bursa kerja. Berdasarkan hal tersebut, maka pada penelitian ini mengusulkan metode TOPSIS untuk seleksi penerimaan calon karyawan, yang selanjutnya hasil dari proses sistem ini akan dibandingkan dengan metode WPM.

\section{Metode Penelitian}

\subsection{Logika Fuzzy}

Logika fuzzy adalah suatu cara yang tepat untuk memetakan ruang input kedalam suatu ruang output. Logika fuzzy menggunakan ungkapan bahasa untuk menggambarkan nilai variabel. Logika fuzzy bekerja dengan menggunakan derajat keanggotaan dari sebuah nilai yang kemudian digunakan untuk menentukan hasil yang ingin dihasilkan berdasarkan atas spesifikasi yang telah 
ditentukan. Logika fuzzy memetakan ruang input ke ruang output. Antara input dan output ada suatu kotak hitam yang harus memetakan input ke output yang sesuai. Fungsi keanggotaan yang digunakan dalam penelitian ini adalah fungsi segitiga dan fungsi monoton turun, seperti yang tertampil pada Gambar 1 dan Gambar 2.

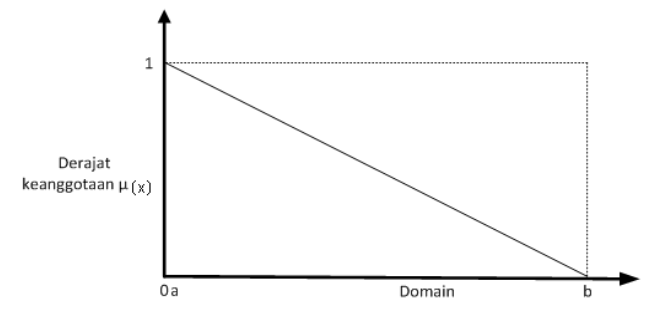

Gambar 1 Representasi monoton turun

Fungsi keanggotaan :

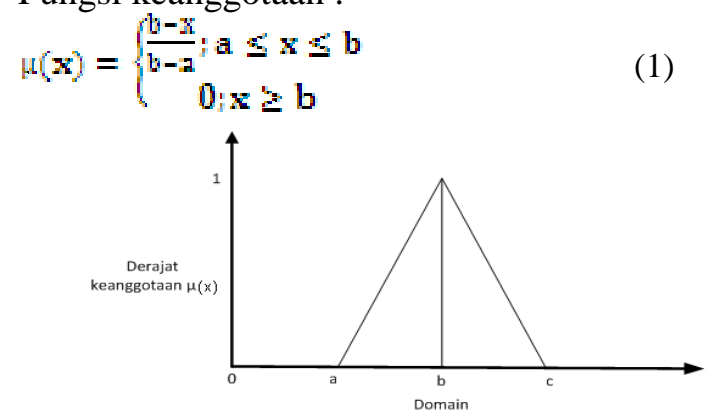

Gambar 2 Kurva segitiga

Fungsi keanggotaan :

$$
H(x)=\left\{\begin{array}{l}
\frac{x-a}{b-a} ; a \leq x \leq b \\
1 ; x=b \\
\frac{c-x}{c-b} ; b \leq x \leq c \\
0 ; x \leq a \text { atou } x \geq c
\end{array}\right.
$$

\subsection{Technique for Order Preference by Similarity to Ideal Solution (TOPSIS)}

Prinsip metode TOPSIS adalah sederhana, dimana alternatif yang dipilih selain memiliki kedekatan dengan solusi ideal positif dan jauh dari solusi ideal negatif. Solusi ideal terbentuk jika sebagai komposit dari nilai kinerja terbaik ditampilan oleh setiap alternatif untuk setiap atribut. Solusi ideal negatif adalah gabungan dari nilai kinerja terburuk. Jarak ke masing-masing kutub kinerja diukur dalam pengertian Euclidean, dengan bobot opsional dari setiap atribut (Kahraman C, [9]). Konsep ini banyak digunakan pada beberapa model MADM untuk menyelesaikan masalah keputusan secara praktis.

Metode TOPSIS adalah salah satu metode yang bisa membantu proses pengambilan keputusan yang optimal untuk menyelesaikan masalah keputusan secara praktis. Hal ini disebabkan konsepnya sederhana dan mudah di pahami, komputasinya efisien dan memiliki kemampuan untuk mengukur kinerja relatif dari alternatif-alternatif keputusan dalam bentuk matematis yang sederhana (Kusumadewi, et al, [10])

Secara umum, prosedur dari metode TOPSIS mengikuti langkah-langkah sebagai berikut :

a. Menentukan matriks keputusan yang ternormalisasi

b. Menghitung matriks keputusan yang ternormalisasi terbobot

c. Menghitung matriks solusi ideal positif dan matriks solusi ideal negatif

d. Menghitung jarak antara nilai setiap alternatif dengan matriks solusi ideal positif dan matrik solusi ideal negatif

e. Menghitung nilai preferensi untuk setiap alternatif

\subsection{Menghitung matriks ternormalisasi}

Topsis membutuhkan rating kinerja tiap calon karyawan pada setiap kriteria atau subkriteria yang ternormalisasi. Matriks ternormalisasi terbentuk dari persamaan (3).

$r_{i j}=\frac{x_{i j}}{\sqrt{E_{i=1}^{m} x_{i j}^{2}}}$

\subsection{Menghitung matriks ternormalisasi terbobot}

Persamaan (5) digunakan untuk menghitung matriks ternormalisasi terbobot, maka harus ditentukan terlebih dahulu nilai bobot yang merepresentasikan preferensi absolute dari pengambil keputusan. Nilai bobot preferensi menunjukkan tingkat kepentingan relatif setiap kriteria atau subkriteria pada persamaan (4).

$\mathrm{W}=\left\{\mathrm{w}_{1}, \mathrm{w}_{2}, \mathrm{w}_{3}, \ldots, \mathrm{w}_{\mathrm{n}}\right\}$

$y_{i j}=w_{i} r_{i j}$

\subsection{Menghitung matriks solusi ideal positif dan matriks solusi ideal negatif}

Solusi ideal positif dan solusi ideal negatif dapat ditentukan berdasarkan rating bobot ternormalisasi. Perlu diperhatikan syarat pada persamaan (6) dan (7) agar dapat menghitung nilai solusi ideal dengan terlebih dahulu menentukan apakah bersifat keuntungan (benefit) atau bersifat biaya (cost).

$A^{+}=\left(y_{1}^{+}, y_{2}^{+}, \ldots, y_{n}^{+}\right)$

$A^{-}=\left(y_{1}^{-}, y_{2}^{-}, \ldots, y_{n}^{-}\right)$

dimana :

$y_{j}^{+}$adalah $-\max y_{i l}$, jika ${ }_{\mathrm{j}}$ adalah atribut keuntungan (benefit)

- min $y_{i y}$, jika $_{\mathrm{j}}$ adalah atribut biaya (cost) 
$y_{j}^{-}$adalah $-\min y_{i j}, \mathrm{jika}_{\mathrm{j}}$ adalah atribut keuntungan (benefit)

$-\max y_{i}$, jika ${ }_{j}$ adalah atribut biaya (cost)

2.6 Menentukan jarak antara nilai setiap alternatif dengan matriks solusi ideal positif dan matriks solusi ideal negatif.

Jarak alterantif $\left(\boldsymbol{D}_{\boldsymbol{i}}^{+}\right)$dengan solusi ideal positif dirumuskan pada persamaan (8).

$D_{i}^{+}=\sqrt{\sum_{i=1}^{n}\left(y_{i}^{+}-y_{i j}\right)^{2}}$

Jarak alternatif dengan solusi ideal negatif dirumuskan pada persamaan (9).

$$
D_{i}^{-}=\sqrt{\sum_{j=1}^{n}\left(y_{i}-y_{i}^{-}\right)^{2}}
$$

\subsection{Menghitung nilai preferensi untuk setiap alternatif}

Nilai preferensi $\left(\mathrm{V}_{\mathrm{i}}\right)$ untuk setiap alternatif dirumuskan dalam persamaan (10).

$V_{i}=\frac{D_{i}^{-}}{D_{\mathrm{r}}^{-}+D_{\mathrm{i}}^{-}}$

\subsection{Weighted Product Model (WPM)}

Yoon (dalam Kusumadewi et al., [10]) menjelaskan metode WPM menggunakan perkalian untuk menghubungkan rating atribut, dimana rating setiap atribut harus dipangkatkan dulu dengan bobot atribut yang bersangkutan. Proses ini sama halnya dengan proses normalisasi. Preferensi untuk alternatif $A_{i}$, menggunakan persamaan (11).

$s_{i}=\prod_{j=1}^{n} x_{i j}^{w /}$

Preferensi relatif untuk setiap alternatif menggunakan persamaan (12).

$$
V_{i}=\frac{\prod_{y=1} x_{i j}^{w /}}{\prod_{f=1}^{n}\left(x_{f}^{-}\right)^{w I}}
$$

\section{HASIL DAN PEMBAHASAN}

Sistem seleksi penerimaan calon karyawan terdiri dari tiga tahapan tes, yaitu tahap 1 tes diferensial, tahap 2 tes technical skill, dan tahap 3 adalah tes wawancara. Calon karyawan dapat mengikuti test tahap selanjutnya apabila telah lulus test sebelumnya. Berdasarkan tes tahap 3 yaitu tes wawancara, calon karyawan yang memiliki nilai tertinggi merupakan calon karyawan yang akan direkomendasikan oleh biro terkait untuk diajukan ke biro SDM yang selanjutnya sebagai acuan pengambilan keputusan calon karyawan tersebut layak bergabung dengan institusi.

Sampel perhitungan untuk tahap satu tes diferensial dilakukan pada data nilai hasil tes diferensial calon karyawan yang melamar pada biro keuangan dengan jenjang pendidikan S1 (strata satu) berjumlah 10 calon karyawan, data dapat dilihat pada Tabel 1, data bobot kriteria dapat dilihat pada Tabel 2, dan data type kriteria ditampilkan pada Tabel 3.

Tabel 1 Nilai alternatif (calon karyawan) untuk

\begin{tabular}{|l|c|c|c|c|c|c|c|}
\hline & \multicolumn{7}{|c|}{ Nilai Kriteria } \\
\cline { 2 - 8 } Alternatif & IQ & $\begin{array}{c}\text { Ko } \\
\text { nkr } \\
\text { it } \\
\text { Pra } \\
\text { ktis }\end{array}$ & $\begin{array}{c}\text { K. } \\
\text { Lo } \\
\text { gik } \\
\text { a }\end{array}$ & $\begin{array}{c}\text { K. } \\
\text { Ba } \\
\text { has } \\
\text { a }\end{array}$ & $\begin{array}{c}\text { K. } \\
\text { Hit } \\
\text { un } \\
\text { g }\end{array}$ & $\begin{array}{c}\text { Ab } \\
\text { str } \\
\text { ak } \\
\text { si }\end{array}$ & $\begin{array}{c}\text { K. } \\
\text { Analisa }\end{array}$ \\
\hline Alternatif 1 & 80 & 65 & 75 & 85 & 80 & 65 & 74 \\
\hline Alternatif 2 & 75 & 66 & 80 & 77 & 80 & 60 & 70 \\
\hline Alternatif 3 & 80 & 60 & 80 & 68 & 85 & 70 & 85 \\
\hline Alternatif 4 & 50 & 65 & 50 & 73 & 55 & 73 & 50 \\
\hline Alternatif 5 & 85 & 68 & 60 & 75 & 80 & 58 & 80 \\
\hline Alternatif 6 & 60 & 70 & 60 & 55 & 73 & 71 & 70 \\
\hline Alternatif 7 & 60 & 50 & 60 & 40 & 60 & 65 & 50 \\
\hline Alternatif 8 & 80 & 60 & 70 & 65 & 80 & 40 & 50 \\
\hline Alternatif 9 & 40 & 75 & 64 & 70 & 60 & 75 & 75 \\
\hline Alternatif 10 & 70 & 50 & 80 & 70 & 85 & 60 & 65 \\
\hline
\end{tabular}

masing-masing kriteria pada tahap 1 tes diferensial

Tabel 2 Bobot preferensi masing-masing kriteria untuk biro keuangan pada tes diferensial

\begin{tabular}{|l|c|}
\hline \multicolumn{1}{|c|}{ Kriteria } & Bobot \\
\hline IQ & 1 \\
\hline Konkrit Praktis & 0.25 \\
\hline Kemampuan Logika & 0.75 \\
\hline Kemampuan Konsep Bahasa & 0.5 \\
\hline Kemampuan Konsep Hitung & 1 \\
\hline Abstraksi & 0.25 \\
\hline Kemampuan Analisa & 0.75 \\
\hline
\end{tabular}

Tabel 3 Tipe kriteria biro keuangan pada tes diferensial

\begin{tabular}{|l|c|}
\hline \multicolumn{1}{|c|}{ Kriteria } & Type \\
\hline IQ & Benefit \\
\hline Konkrit Praktis & Benefit \\
\hline Kemampuan Logika & Benefit \\
\hline Kemampuan Konsep Bahasa & Benefit \\
\hline Kemampuan Konsep Hitung & Benefit \\
\hline Abstraksi & Cost \\
\hline Kemampuan Analisa & Benefit \\
\hline
\end{tabular}

Berdasarkan data nilai calon karyawa, bobot kriteria, dan type kriteria pada tahap 1 tes diferensial maka setelah dilakukan proses perhitungan sesuai dengan tahap metode TOPSIS dihasilkan bawah alternatif (calon karyawan) yang dinyatakan lulus berjumlah 6 orang sehingga berhak untuk melanjutkan tes tahap berikutnya yaitu tes technical skill. Hasil proses perhitungan tahap 1 tes diferensial dapat dilihat pada Gambar 3.

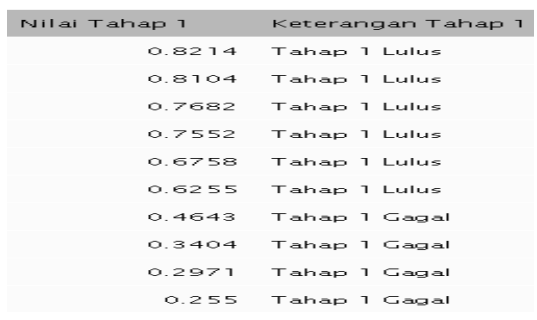


Gambar 3 Hasil proses perhitungan dengan metode TOPSIS untuk tahap 1 tes diferensial

\subsection{Proses Penghitungan pada Tahap Dua Tes Technical Skill}

Fuzzy TOPSIS diterapkan pada proses tahap 2 dan tahap 3, secara umum menggunakan fungsi segitiga berbobot sehingga menghasilkan kenaikan nilai yang signifikan maka tepat digunakan untuk penyelesaian pada kasus ini, karena mampu mengcover setiap nilai input. Sehingga dengan penerapan fungsi segitiga berbobot dalam hal ini fungsi segitiga yang ideal dapat meningkatkan obyektivitas penilaian.

Calon karyawan yang telah lulus tahap satu tes diferensial selanjutnya akan mengikuti tes technical skill, yang terdiri dari empat kriteria yaitu kecepatan, ketelitian, reaktif dan responsif. Fungsi keanggotaan yang digunakan pada tahapan ini ada dua yaitu fungsi monoton turun untuk merepresentasikan kriteria kecepatan dan fungsi segitiga untuk merepresentasikan kriteria ketelitian, reaktif, dan responsif. Adapun data yang digunakan pada tahap 2 tes technical skill adalah data nilai alternatif (calon karyawan) dapat dilihat pada Tabel 4, data bobot kriteria dapat dilihat pada Tabel 5, dan data type riteria dapat dilihat pada Tabel 6.

Tabel 4 Nilai alternatif (Calon karyawan) untuk masing-masing kriteria pada tahap 2 tes technical skill

\begin{tabular}{|l|c|c|c|c|}
\hline \multirow{2}{*}{ Alternatif } & \multicolumn{4}{|c|}{ Nilai Kriteria } \\
\cline { 2 - 5 } & $\begin{array}{c}\text { Ke- } \\
\text { cepatan }\end{array}$ & $\begin{array}{c}\text { Ke- } \\
\text { telitian }\end{array}$ & $\begin{array}{c}\text { Re- } \\
\text { aktif }\end{array}$ & $\begin{array}{c}\text { Res- } \\
\text { ponsif }\end{array}$ \\
\hline Alternatif 1 & 10 & 80 & 65 & 90 \\
\hline Alternatif 2 & 20 & 50 & 80 & 60 \\
\hline Alternatif 3 & 5 & 70 & 80 & 80 \\
\hline Alternatif 5 & 30 & 85 & 60 & 85 \\
\hline Alternatif 8 & 10 & 75 & 70 & 70 \\
\hline Alternatif 10 & 10 & 70 & 65 & 70 \\
\hline
\end{tabular}

Tabel 5 Bobot preferensi kriteria pada tes technical skill

\begin{tabular}{|l|c|}
\hline \multicolumn{1}{|c|}{ Kriteria } & Bobot \\
\hline Kecepatan & 1 \\
\hline Ketelitian & 1 \\
\hline Reaktif & 0.75 \\
\hline Responsif & 0.5 \\
\hline
\end{tabular}

Tabel 6 Tipe kriteria pada tes technical skill

\begin{tabular}{|l|c|}
\hline \multicolumn{1}{|c|}{ Kriteria } & Type \\
\hline Kecepatan & Benefit \\
\hline Ketelitian & Benefit \\
\hline Reaktif & Benefit \\
\hline Responsif & Benefit \\
\hline
\end{tabular}

Setelah dilakukan proses perhitungan pada tahapan tes technical skill, alternatif yang dinyatakan lulus untuk biro keuangan dengan jenjang pendidikan $\mathrm{S} 1$ adalah berjumlah 4 calon karyawan, sehinga berhak untuk melanjutkan tes ditahap berikutnya yaitu tes wawancara. Hasil proses perhitungan tahap 2 tes technical skill dapat dilihat pada Gambar 4.

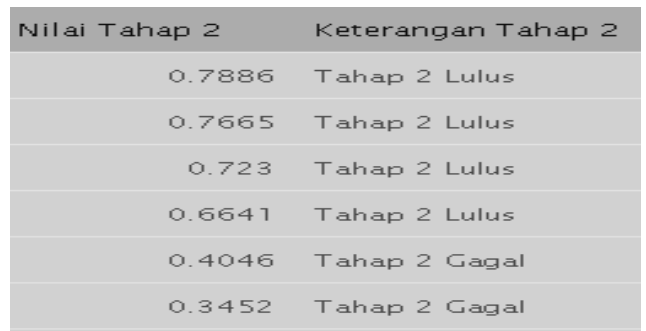

Gambar 4 Hasil proses perhitungan dengan metode TOPSIS untuk tahap 2 tes technical skill

\subsection{Proses Penghitungan pada Tahap Tiga Tes Wawancara}

Calon karyawan yang telah lulus tahap dua tes technical skill selanjutnya akan mengikuti tes wawancara, yang terdiri dari empat kriteria yaitu penampilan, kepribadian, kemampuan, dan tuntutan kondisi kerja. Masing-masing kriteria memiliki sub kriteria, untuk kriteria penampilan terdiri dari subkriteria jasmani, subkriteria pakaian, dan subkriteria atribut. Kriteria kepribadian terdiri dari subkriteriaa etika, komunikasi, motivasi, dan keyakinan diri. Kriteria kemampuan terdiri dari subkriteria nilai ijazah/IPK, subkriteria pengalaman organisasi, subkriteria asal pendidikan, subkriteria ketrampilan bidang komputer, subkriteria ketrampilan bidang bahasa, subkriteria ketrampilan lainnya dan subkriteria prestasi yang pernah diraih. Fungsi keanggotaan yang digunakan adalah fungsi segitiga baik untuk kriteria dan subkriteria. Hasil perhitungan dari subkriteria akan menjadi nilai inputan untuk kriteria. Adapun data pada tahap 3 tes wawancara yaitu data nilai alternatif (calon karyawan) dapat dilihat pada Tabel 7, data bobot subkriteria pada kriteria penampilan dapat dilihat pada Tabel 8, dan data type subkriteria pada kriteria penampilan dapat dilihat pada Tabel 9.

Tabel 7 Nilai alternatif (calon karyawan) untuk masing-masing subkriteri dalam kriteria penampilan pada tahap 3 tes wawancara

\begin{tabular}{|l|c|c|c|}
\hline \multirow{2}{*}{ Alternatif } & \multicolumn{3}{|c|}{ Nilai subkriteria } \\
\cline { 2 - 4 } & Jasmani & Pakaian & Atribut \\
\hline Alternatif 1 & 80 & 70 & 65 \\
\hline Alternatif 3 & 75 & 60 & 75 \\
\hline Alternatif 8 & 50 & 60 & 60 \\
\hline Alternatif 10 & 70 & 70 & 75 \\
\hline
\end{tabular}


Tabel 8 Bobot preferensi subkriteria untuk kriteria penampilan pada tes wawancara

\begin{tabular}{|l|c|}
\multicolumn{1}{|c|}{ penampilan pada tes wawancara } \\
\hline Kasmani & Bobot \\
\hline Pakaian & 0.75 \\
\hline Atribut & 0.50 \\
\hline
\end{tabular}

Tabel 9 Tipe subkriteria untuk kriteria penampilan pada tes wawancara

\begin{tabular}{|l|c|}
\hline \multicolumn{1}{|c|}{ Kriteria } & Type \\
\hline Jasmani & Benefit \\
\hline Pakaian & Cost \\
\hline Atribut & Cost \\
\hline
\end{tabular}

Setelah dilakukan proses perhitungan, didapatkan nilai preferensi untuk setiap alternatif sebagai berikut :

\begin{tabular}{l|l|l|l|}
0.8078 & 0.7855 & 0.2229 & 0.6026 \\
\hline
\end{tabular}

Hasil nilai preferensi inilah selanjutnya akan menjadi nilai input untuk kriteria penampilan. Subkriteria dalam kriteria kepribadian, kriteria kemampuan, dan kriteria tuntutan kondisi kerja dilakukan tahapan yang sama seperti pada kriteria penampilan. Berikut ini akan ditampilkan hasil terahir dari masing-masing kriteria tesebut yaitu pada nilai preferensi.

Nilai preferensi untuk setiap alternatif pada subkriteria dalam kriteria kepribadian.

\begin{tabular}{l|l|l|l|}
0.8245 & 0.8328 & 0.2244 & 0.4646 \\
\hline
\end{tabular}

Nilai preferensi untuk setiap alternatif pada subkriteria dalam kriteria kemampuan.

\begin{tabular}{|l|l|l|l|}
\hline 0.6473 & 0.0628 & 0.629 & 0.7725 \\
\hline
\end{tabular}

Nilai preferensi untuk setiap alternatif pada subkriteria dalam kriteria tuntutan kondisi kerja.

\begin{tabular}{|l|l|l|l|}
0.5080 & 0.7614 & 0.1846 & 0.8527 \\
\hline
\end{tabular}

Setelah didapatkan nilai untuk masingmasing subkriteria pada kriteria penampilan, kepribadian, kemampuan dan tuntutan kondisi kerja, data dapat dilihat pada Tabel 10, selanjutnya dilakukan proses perhitungan sehingga mendapatkan nilai preferensi akhir untuk tes wawancara.

Tabel 10 Nilai alternatif untuk masing-masing kriteria

\begin{tabular}{|c|c|c|c|}
\hline 0.8078 & 0.8245 & 0.6473 & 0.5080 \\
\hline 0.7855 & 0.8328 & 0.0628 & 0.7614 \\
\hline 0.2229 & 0.2244 & 0.6290 & 0.1846 \\
\hline 0.6026 & 0.4646 & 0.7725 & 0.8527 \\
\hline
\end{tabular}

Nilai inilah selanjutnya dilakukan proses perhitungan sesuai dengan tahapan TOPSIS yaitu dari membuat matriks keputusan ternormalisasi, membuat matriks ter-normalisasi terbobot, menentukan matriks solusi ideal positif dan matriks solusi ideal negatif, menentukan jarak antara nilai setiap alterantif dengan matriks solusi ideal positif dan matriks solusi ideal negatif dan pada akhirnya menentukan nilai preferensi untuk setiap alternatif, sehingga dihasilkan nilai seperti yang tertampil pada Gambar 5.

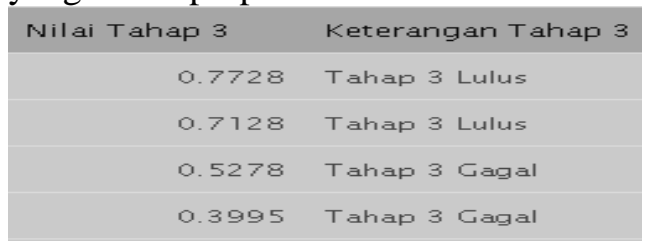

Gambar 5 Hasil proses perhitungan dengan metode TOPSIS untuk tahap 3 tes wawancara

Setelah melalui beberapa tahapan tes, dari 10 calon karyawan tersaring pada tes diferensial yang lulus ada 6 calon karyawan, dan setelah melalui tahapan kedua tes technical skill yang lulus 4 calon karyawan dan pada tahap ke tiga tes wawancara yang dinyatakan lulus 2 calon karyawan. Nilai preferensi yang lebih besar menunjukan bahwa calon karyawan tersebut lebih dipilih, yang akan direkomendasikan untuk pengambilan keputusan calon karyawan yang layak bergabung dengan institusi.

\subsection{Validasi}

Hal terpenting dalam validasi hasil penelitian ini adalah melakukan pengujian terhadap modul yang berfungsi melakukan perhitungan untuk metode TOPSIS. Turban [11] menyatakan validasi adalah bagian dari evaluasi yang berhubungan dengan kinerja sistem. Secara sederhana dinyatakan bahwa validasi adalah sebuah proses untuk membangun sebuah right system, yaitu sistem yang mempunyai kinerja dalam keakurasian yang dapat diterima (acceptable). Validasi ini diterapkan untuk tiap tahapan, namun pada paper ini diambil hasil pada tahap 3 tes wawancara karena merupakan tahap akhir dari sistem seleksi calon karyawan. Hasil perbandingan tahap 3 tes wawancara data dapat dilihat pada Tabel 11.

Tabel 11 Perbandingan hasil perhitungan pada tahap 3 tes wawancara dengan menggunakan 3 model

\begin{tabular}{|l|c|c|c|}
\hline Alternatif & $\begin{array}{c}\text { Sistem seleksi } \\
\text { penerima-an } \\
\text { calon } \\
\text { karyawan }\end{array}$ & $\begin{array}{c}\text { Ms. } \\
\text { Excell }\end{array}$ & Matlab \\
\hline Alternatif 1 & 0.7728 & 0.7728 & 0.7728 \\
\hline Alternatif 3 & 0.5278 & 0.5278 & 0.5278 \\
\hline Alternatif 8 & 0.3995 & 0.3995 & 0.3995 \\
\hline Alternatif 10 & 0.7128 & 0.7128 & 0.7128 \\
\hline
\end{tabular}

Berdasarkan tabel 11 dapat disimpulkan validasi dari sistem seleksi penerimaan calon 
karyawan dapat diterima, karena telah dibuktikan dengan perhitungan menggunakan tools lain dan secara umum menghasilkan nilai yang sama.

\subsection{Perbandingan Hasil Perhitungan dengan Metode TOPSIS dan WPM}

Setelah dilakukan validasi, selanjutnya hasil proses perhitungan dengan menggunakan metode TOPSIS dibandingkan dengan hasil proses perhitungan dengan menggunakan metode yang berbeda yaitu Weighted Product Model (WPM). Proses perhitungan menggunakan sampel data yang sama, dan dilakukan untuk setiap tahapan tes. Tabel 12 menampilkan hasil perhitungan untuk tahap 3 tes wawancara.

Tabel 12 Perbandingan hasil perhitungan pada tes wawacara dengan metode TOPSIS dan WPM

\begin{tabular}{|l|c|c|}
\hline \multirow{2}{*}{ Alternatif } & \multicolumn{2}{|c|}{ Metode } \\
\cline { 2 - 3 } & TOPSIS & WPM \\
\hline Alternatif 1 & 0.7728 & 0.2609 \\
\hline Alternatif 10 & 0.7128 & 0.2560 \\
\hline Alternatif 3 & 0.5278 & 0.2430 \\
\hline Alternatif 8 & 0.3995 & 0.2401 \\
\hline
\end{tabular}

Berdasarkan sampel data yang sama, hasil proses metode TOPSIS dan WPM untuk masingmasing tahapan, menunjukkan nilai berbeda, namun secara rangking menunjukkan hasil yang sama.

\section{KESIMPULAN}

Lestari [11] mengemukakan beberapa kesimpulan dari hasil penelitiannya yaitu implementasi metode fuzzy TOPSIS pada sistem seleksi penerimaan calon karyawan, adalah sebagai berikut:

1. Berdasarkan sampel data yang sama, hasil proses metode TOPSIS dan WPM, menunjukkan nilai berbeda, namun secara rangking menunjukkan hasil yang sama.

2. Metode WPM bisa digunakan untuk permasalahan satu dimensi dan multi dimensi, sedangkan pada metode TOPSIS lebih tepat untuk menyelesaikan permasalahan multi dimensi seperti pada sistem seleksi penerimaan calon karyawan, dengan banyak kriteria sebagai komponen penilaian untuk setiap alternatif (calon karyawan).

3. Implementasi metode TOPSIS dalam sistem seleksi penerimaan calon karyawan memiliki kelemahan yaitu tidak bisa digunakan untuk melakukan penilaian jika yang dinilai hanya satu calon karyawan. Namun metode WPM juga kurang tepat digunakan untuk menyelesaikan kasus ini dikarenakan adanya ketentuan batasan nilai minimal untuk calon karyawan.

4. Fungsi segitiga berbobot yang diterapkan dalam sistem seleksi penerimaan calon karyawan mampu meningkatkan obyektivitas penilaian. Hal ini berlaku jika fungsi yang digunakan adalah fungsi segitiga yang ideal.

5. Faktor yang mempengaruhi hasil perhitungan dengan menggunakan metode TOPSIS adalah bobot kriteria atau subkriteria, bobot preferensi, sifat (type) dari kriteria atau subkriteria.

6. Hasil proses perhitungan sistem seleksi penerimaan calon karyawan bisa diterima atau dinyatakan valid, hal ini didasarkan atas perbandingan hasil perhitungan dengan perangkat lunak Ms. Excel dan Matlab yang secara umum hasil perhitungan menunjukkan nilai yang sama.

Saran yang diberikan dalam upaya pengembangan sistem seleksi penerimaan calon karyawan pada penelitian selanjutnya adalah :

1. Perlu adanya pengembangan lebih lanjut terhadap metode yang digunakan dalam sistem seleksi penerimaan calon karyawan agar sistem mampu melakukan proses perhitungan baik satu dimensi maupun multi dimensi dengan hasil yang lebih baik.

2. Sistem yang dibuat dapat digunakan untuk kasus lain atau untuk instansi lain, tetapi hal ini memerlukan evaluasi lebih lanjut pada kriteria penilaian yang akan dipakai.

3. Perlu pengembangan lebih lanjut untuk sistem seleksi penerimaan calon karyawan untuk meningkatkan performa dengan mengunakan metode yang berbeda atau mengkombinasikan tehnik AI dengan FMCDM.

\section{DAFTAR PUSTAKA}

[1] Salehi, M., dan Moghaddam, R.T., 2008, Project Selection by Using a Fuzzy TOPSIS Technique, International Journal of Computer Information, and System Science, and Engineering 2.

[2] Wang, Y.J., dan Kao, C.S., 2008, Evaluating the operation performance of airport by FMCDM, Fifth International Conference on Fuzzy System and Knowledge Discovery.

[3] Hu, Y., Wu, S., dan Cai, L., 2009, Fuzzy Multi Criteria Decision Making TOPSIS for Distribution Center Location Selection, International Conference on Network Security, Wireless Communications and Trusted Computing.

[4] Sukerti, N.K., 2010, Sistem Pendukung Keputusan Penentuan Desa Penerima Bantuan Program Community Based Development (CBD) Bali Sejahtera Menggunakan Metode TOPSIS, Tesis, Magister Ilmu Komputer, Program Pascasarjana, Universitas Gadjah Mada, Yogyakarta. 
[5] Santoso, H., 2003, Sistem Pendukung Keputusan Penerimaan Staff Akademik (Studi Kasus pada STMIK Bumigora Mataram), Tesis, Magister Ilmu Komputer, Program Pascasarjana, Universitas Gadjah Mada, Yogyakarta.

[6] Rahino, C.B.T.G., 2006, Sistem Pendukung Keputusan Penerimaan Staff Hotel (Studi Kasus pada Balihai Resot \& Spa). Tesis, Magister Ilmu Komputer. Program Pascasarjana, Universitas Gadjah Mada, Yogyakarta.

[7] Santoso, L.W., Setiawan, A., dan Stanly, J.R., 2009, Pembuatan Aplikasi Sistem Seleksi Calon Pegawai dengan Metode Analytic Network Process (ANP) di PT. X, Universitas Kristen Petra, Surabaya.
[8] Akhiro R., 2008, Studi Multi Criteria Decision Making (MCDM) untuk Recommender System Bursa Tenaga Kerja, Tesis Program Studi Magister Informatika, Sekolah Teknik Elektro dan Informatika, Institut Teknologi Bandung, Bandung.

[9] Kahraman, C., 2008, Fuzzy Multi Ckriteria Decision Making, Springer, New York.

[10] Kusumadewi, S., Hartati, S., Harjoko, A., Wardoyo, R., 2006, Fuzzy Multi Atribut Decision Making (FUZZY MADM), Graha Ilmu, Yogyakarta.

[11] Lestari, S., 2011, Implementasi Metode Fuzzy Technique for Order Preference by Similarity to Ideal Solution (TOPSIS) untuk Seleksi Karyawan. Tesis, Magister Ilmu Komputer. Program Pascasarjana, Universitas Gadjah Mada, Yogyakarta. 